\title{
Manjemen Kepemimpinan Kepala Sekolah Dalam Peningkatan Kinerja Guru di Madrasah Ibtidaiyah Mujahidin Loloan Barat
}

\author{
Imam Turmudi \\ Institut Agama Islam Negeri (IAIN) Jember \\ imamturmudi@iain-jember.ac.id
}

Abstract

In running a school organization, a leader must be able to drive and run the organization. This means that a leader must be able to bring about change, because change is the main goal of leadership. Research objectives include describing the leadership style of the principal in Madrasah Ibtidaiyah Mujahidin Loloan Barat. This research uses a qualitative approach with a descriptive type. Data collection techniques used three ways, namely observation, interviews and documentation. The collected data were then analyzed by following the data reduction procedure, data display, and conclusions. The results of this study concluded that: First, the leadership style of the school principal at Madrasah Ibtidaiyah Mujahidin Loloan Barat predominantly uses democratic leadership styles and in urgent decision making, the leadership style used is autocratic or authoritarian leadership style. Second, the performance of teachers at Madrasah Ibtidaiyah Mujahidin Loloan Barat can be said to be very good and high level because by looking at teacher competencies which include pedagodic competence, personality competence, social competence, and professional competence. Third, the leadership management of the principal in improving teacher performance at Madrasah Ibtidaiyah Mujahidin West Loloan can be said to be very good by using democratic and authoritarian leadership styles and supervision of classroom observations in activities, namely daily, weekly, monthly, and semester activities.

Keyword: Principal Leadership, Management, Teachers 
Abstrak

Dalam menjalankan organisasi sekolah, seorang pemimpin harus mampu mengemudikan dan menjalankan organisasinya. Artinya seorang pemimpin harus mampu membawa perubahan, karena perubahan adalah tujuan pokok dari kepemimpinan. Tujuan penelitian di antaranya untuk mendeskripsikan gaya kepemimpinan kepala sekolah di Madrasah Ibtidaiyah Mujahidin Loloan Barat. Penelitian ini menggunakan pendekatan kualitatif dengan jenis deskriptif. Teknis pengumpulan data menggunakan tiga cara yaitu observasi, wawancara dan dokumentasi. Data yang terkumpul kemudian dianalisis dengan mengikuti prosedur Reduksi data, Display data, dan kesimpulan Hasil dari penelitian ini disimpulkan bahwa: Pertama, Gaya kepemimpinan kepala sekolah di Madrasah Ibtidaiyah Mujahidin Loloan Barat lebih dominan menggunakan gaya kepemimpinan demokratis dan dalam pengambilan keputusan yang mendesak, gaya kepemimpinan yang digunakan adalah gaya kepemimpinan otokrasi atau otoriter. Kedua, Kinerja guru di Madrasah Ibtidaiyah Mujahidin Loloan Barat dapat dikatakan sangat baik dan tingkat tinggi karena dengan melihat kompetensi guru yang meliputi kompetensi paedagodik, kompetensi kepribadian, kompetensi sosial, dan kompetensi profesional. Ketiga, Manajemen kepemimpinan kepala sekolah dalam peningkatan kinerja guru di Madrasah Ibtidaiyah Mujahidin Loloan Barat dapat dikatakan sangat baik dengan menggunakan gaya kepemimpinan demokratis dan otoriter serta supervisi observasi kelas dalam kegiatan-kegiatan, yaitu kegiatan harian, mingguan, bulanan, dan semester.

Keyword: Kepemimpinan Kepala Sekolah, Manajemen, Guru 


\section{PENDAHULUAN}

Masalah kepemimpinan dari dulu hingga sekarang selalu menjadi perhatian yang menarik dan senantiasa memberikan daya pikat yang kuat bagi setiap orang. Menurut Fremont: "Kepemimpinan menduduki posisi sentral dalam suatu organisasi, pemimpinlah yang menentukan perubahan, pembaharuan, perbaikan, dan menjamin kemamapuan organisasi untuk terus berprestasi di masa depan". ${ }^{1}$

Ungkapan lain juga menyebutkan: "Suatu organisasi dapat dikatakan akan berhasil atau bahkan gagal sebagian ungkapan yang menyatakan pemimpinlah yang bertanggung jawab atas kegagalan pelaksanaan suatu pekerjaan". ${ }^{2}$ Ungkapan ini membuktikan betapa kompleknya tugas dan tanggung jawab pemimpin dalam membawa suatu lembaga menuju arah yang lebih baik atau pemimpin adalah ahli strategi yang menetapkan visi dan misi organisasi serta memusatkan perhatian pada cara-cara agar organisasi mencapai tujuan. Dengan memusatkan perhatian pada suatu visi, pemimpin mengoperasikan sumber daya yang ada dengan keragaman karakteristik yaitu meliputi kecakapan teknik (misal : mengetahui tentang prosedur tugas dan perlengkapan) dan kecakapan hubungan antar manusia (misalnya: menyadari keutuhan bawahan dan kemampuan bergaul dengan bawahan)".3

Pemimpin yang cakap tidak hanya mampu mengusahakan bahwa pekerjaan dapat dilaksanakan dengan baik, produktif, dan efisien, tepat pada waktunya dengan kualitas tinggi, tetapi juga dapat menolong orangorang dalam organisasi, mengetahui rasa harga diri dan kepuasan dalam bekerja. "Para pemimpin yang berhasil seringkali menginspirasikan pengikutnya untuk mencapai hasil yang lebih tinggi dengan menunjukkan pada mereka bagaimana pekerjaan mereka dapat memberikan sumbangan yang bermanfaat bagi organisasi yaitu tetap menjaga antara kepentingan organisasi dan kepentingan individu". ${ }^{4}$ Sehingga kepentingan organisasi atau kelompok dapat mengarahkan dan memotivasi individu untuk bekerjasama dalam kelompok dalam rangka mewujudkan tujuan organisasi.

\footnotetext{
${ }^{1}$ Kast, Fremont dan Resenzweig, Organisasi dan Manajemen 2, (Jakarta: Bumi Aksara,1991), h. 571

${ }^{2}$ Miftah Thoha, Kepemimpinan dalam Manajemen, (Jakarta: Raja Grafindo Persada, 1995), h.1

3 Kenneth N. Wexlwy, Gary A. Yuki, Perilaku Organisasi dan Psikologi Personalia, (Jakarta: Rineka Cipta,1992), h. 191-192

4 E. Mulyasa, Manajemen Berbasis Sekolah (Konsep, Strategi, dan Implementasi), (Bandung: Remaja Rosdakarya,2005), h. 107
} 
Kepentingan individu bergabung dengan organisasi dengan harapan untuk mendapatkan imbalan dari partisipasinya. Menurut Warren Bennis \& Bart Nanus: "Imbalan itu bisa berarti kepentingan ekonomi atau berbagai kepentingan psikososial: harga diri, prestasi dan eksistensi yang berarti sebagaimana individu mendapat imbalan atas dari usahanya menemukan tempat di masyarakat, imbalan itu bisa berupa mungkin ekonomis (keuntungan, pertumbuhan, akses ke berbagai sumber daya) dan atau psikososial (prestise, keabsahan, kekuasaan, dan pengkuan)". ${ }^{5}$

Kepemimpinan dalam islam dijelaskan dalam banyak ayat dan hadis Nabi, baik secara langsung menjelaskan pengertian dari kepemimpinan maupun tidak. Diantaranya seperti yang telah dijelaskan dalam surat An-Nahl, ayat: 36, sebagai berikut :

Artinya: Dan sungguhnya Kami telah mengutus Rasul pada tiaptiap umat (untuk menyerukan): "Sembahlah Allah (saja), dan jauhilah Thaghut itu", Maka di antara umat itu ada orang-orang yang diberi petunjuk oleh Allah dan ada pula di antaranya orangorang yang telah pasti kesesatan baginya. Maka berjalanlah kamu dimuka bumi dan perhatikanlah bagaimana kesudahan orangorang yang mendustakan (rasul-rasul). (An-Nahl: 36)

Dalam surat tersebut dijelaskan bahwa hakikat diutusnya para rasul kepada manusia sebenarnya hanyalah untuk memimpin ummat dan mengeluarkannya dari kegelapan menuju kepada aqidah yang lurus, yakni hanya menyembah Allah Yang Esa.

Dalam menjalankan organisasi sekolah seorang pemimpin harus mampu mengemudikan dan menjalankan organisasinya. Artinya seorang pemimpin harus mampu membawa perubahan, karena perubahan adalah tujuan pokok dari kepemimpinan. Sementara pada hakikatnya pemimpin harus bertanggung jawab terhadap apa yang sedang dipimpinnya, sebagaimana hadits Nabi Muhammad SAW, :

"Kalian semua adalah pemimpin dan ditanya atas kepemimpinannya, seorang suami adalah pemimpin dalam keluarganya dan bertanggung jawab atas kepemimpinannya, seorang istri adalah pemimpin pada rumah tanggannya, dan bertangga jawab atas kepemimpinannya, seorang pembantu (karyawan) adalah pemimpin pada harta majikannya dan bertanggung jawab atas

${ }^{5}$ Warren Bennis \& Bart Nanus, Kepemimpinan Strategi dalam Mengemban Tanggung Jawab. (Jakarta: Gelora Aksara Pratama, 1990), h. 56 
kepemimpinannya, dan kemau semua pemimpin dan ditanya atas apa yang dipimpinnya”. (HR. Bukhari Muslim dari Abi Umar) ${ }^{6}$

Dalam mengelola organisasi sekolah, kepala sekolah dapat menekankan salah satu gaya kepemimpinan yang ada. Gaya kepemimpinan mana yang paling tepat diterapkan masih menjadi pertanyaan. Karakteristik sekolah sebagai organisasi pendidikan akan berpengaruh terhadap keefektifan gaya kepemimpinan yang diterapkan. Sebuah organisasi hanya akan bergerak. jika kepemimpinan yang ada di dalamnya berhasil dan efektif. Gaya kepemimpinan banyak mempengaruhi keberhasilan seorang pemimpin dalam mempengaruhi perilaku bawahannya. Istilah gaya secara kasar adalah sama dengan cara yang dipergunakan pemimpin di dalam mempengaruhi para pengikutnya. Kepemimpinan suatu organisasi perlu mengembangkan staf dan membangun iklim motivasi yang menghasilkan tingkat produktivitas yang tinggi, maka pemimpin perlu memikirkan gaya kepemimpinannya. Gaya kepemimpinan merupakan norma perilaku yang digunakan oleh seseorang pada saat orang tersebut mencoba mempengaruhi perilaku orang lain. Pada dasarnya, ada tiga gaya kepemimpinan seperti yang dikembangkan oleh Lippit, dan White yaitu: "Otokratik/Otokrasi, Demokratik, dan Laissez-faire". ${ }^{7}$

Kepala sekolah sebagai pemimpin bertipe laissez faire menurut Rifa'I "menghendaki semua komponen pelaku pendidikan menjalankan tugasnya dengan bebas". 8

Oleh karena itu tipe kepemimpinan bebas merupakan kemampuan mempengaruhi orang lain agar bersedia bekerja sama untuk mencapai tujuan yang telah ditetapkan dengan cara berbagai kegiatan diserahkan pada bawahan. Jadi pengertian laissez faire adalah memberikan kepada orang lain dengan prinsip kebebasan, termasuk bawahan untuk melaksanakan tugasnya dengan bebas sesuai dengan kehendak bawahan dan tipe ini dapat dilaksanakan di sekolah yang memang benar-benar mempunyai sumber daya manusia maupun alamnya dengan baik dan mampu merancang semua kebutuhan sekolah dengan mandiri.

Dari gaya kepemimpinan laissez-faire dalam konteks pendidikan Indonesia sangat sulit untuk dilaksanakan karena keadaan pendidikan kita

${ }^{6}$ Abi Abdillah MuhammadIbn Ismailal-Bukhori, Al Jami' Al-Shahih, (Al Qahirah: Al Matba'ah al Salafiyah,1403 H), h. 328

7 http://meetabied.wordpress.com/2009/12/24/gaya-kepemimpinan/ diakses pada tanggal 21 Maret 2021

${ }^{8}$ M. Moh. Rifa'I, Administrasi dan Supervisi Pendidikan, (Bandung: Jemmar, 1986), h, 38 . 
masih mengalami beberapa kendala mulai dari masalah pendanaan, sumber daya manusia, kemandirian, dan lain sebagainya. Menurut Imam Suprayogo: "Tipe kepemimpinan ini sangat cocok sekali untuk orang yang betul-betul dewasa dan benar-benar tau apa tujuan dan cita-cita bersama yang harus dicapai". 9

"Pemimpin yang bertipe demokratis menafsirkan kepemimpinannya bukan sebagai diktator, melainkan sebagai pemimpin di tengah-tengah anggota kelompoknya". ${ }^{10}$ Dalam melaksanakan tugasnya, ia mau menerima dan bahkan mengharapkan pendapat dan saran-saran dari kelompoknya. Juga kritik yang membangun dapat ia terima sebagai umpan balik dan dijadikan bahan pertimbangan dalam tindakan-tindakan selanjutnya. Pemimpin selalu berusaha memupuk rasa kekeluargaan dan membangun semangat serta memotivasi para anggotanya dalam mengembangkan diri.

Adanya gaya kepemimpinan kepala sekolah yang bermacammacam sesuai yang tersebut diatas, diharapkan mampu sebagai agen perubahan dalam sekolah sehingga mempunyai peran aktif dalam meningkatkan kualitas pendidikan.

Adapun indikator kinerja guru dapat didasari dengan mengacu pada Peraturan Menteri Pendidikan Nasional Republik Indonesia No. 16 Tahun 2007 tentang kualifikasi akademik dan kompetensi guru yang meliputi kompetensi paedagodik, kompetensi kepribadian, kompetensi sosial, dan kompetensi profesional.

Dalam hal peranan guru, Ngalim Purwanto menyebutkan: " Peran guru tidak terlepas dari penerapan gaya kepemimpinan yang ada dalam masing-masing lembaga" 11 , akan tetapi masih banyak permasalahan yang menyebabkan menurunnya efektivitas kinerja guru yang muncul disebabkan ketidaksesuaian gaya kepemimpinan yang diterapkan, bahkan tidak jarang pada permasalahan tersebut muncul disebabkan gaya kepemimpinan yang salah karena secara tidak disadari seorang pemimpin dalam memperlakukan atau menerapkan gaya kepemimpinan tersebut dalam rangka menjalankan kepemimpinannya menurut caranya sendiri dan cara-cara yang digunakannya merupakan pencerminan sifat-sifat dasar kepribadian seorang pemimpin walaupun pengertian ini tidak mutlak.

9 Imam Suprayogo, Revormulasi Visi Pendidikan Islam, (Malang: Stain Press,1999), Cet.1, h, 167

10 Abdul Aziz Wahab, Anatomi Organisasi dan Kepemimpinan Pendidikan, (CV. Alfabeta,2008), cet.1, h, 135.

11 M.Ngalim Purwanto, Administrasi dan Supervisi Pendidikan, (Bandung: Remaja Rosdakarya, 2006), h.48 
Berdasarkan hasil observasi peneliti menemukan bahwa pendidik (guru) sering meninggalkan kelas tanpa memberikan tugas dan juga sering tidak masuk sekolah tanpa keterangan, sehingga menyebabkan kelas kosong dan tidak terkendali.

Hal ini disebabkan oleh pemikiran pemimpin yang salah dalam menganggap bahwa hakekatnya setiap manusia itu sama dan sumber daya manusia didalamnya dapat diperlakukan secara identik. Intinya tidak ada sesuatu yang betul-betul sama dan setiap manusia berbeda secara fisik dan kondisi satu dengan yang lainnya. Poinnya adalah bahwa perbedaan ini menuntut perhatian7 agar setiap kerja guru dapat menggali potesnsinya secara penuh sehingga efektivas dapat meningkat dengan memaksimalkan produktivitas kerja. "Produktivitas sebagai salah satu tujuan organisai adalah bagaimana peserta didik, guru, kelompok, dan sekolah pada umumnya mencapai tujuan yang telah ditetapkan". ${ }^{12}$

Dengan indikator yang tidak hanya bersifat kuantitatif, tetapi juga bersifat kualitatif. Dengan kata lain produktivitas merupakan fungsi lain efektivitas dan efesiensi. Efektif artinya mempunyai efek (akibat, pengaruh, kesan), manajer atau mujarab, dapat membawa hasil". ${ }^{13}$ Sedangkan efesiensi merupakan aspek yang sangat penting dalam manajemen sekolah karena sekolah dihadapkan pada masalah sumber dana, dan secara langsung berpengaruh terhadap kegiatan manajemen. Jadi dapat disimpulkan bahwa efektif merupakan ukuran yang menggambarkan sejauh mana sasaran yang dapat dicapai sedangkan efesiensi menggambarkan bagaimana sumber-sumber daya yang dikelola secara tepat dan benar.

Untuk meningkatkan efesiensi dan efektivitas agar dicapai produktivitas yang tinggi, sumber daya manusia harus diaktifkan, dimotovasi, dipacu, dan dibina untuk mencapai tujuan bersama. Hal ini hanya dapat dilaksanakan apabila perencanaan sumber daya manusia diformulasikan dengan baik melalui proses kepemimpinan yang efektif dengan penerapan gaya penerapan yang dinamis, flexibel dan selalu mengadakan pembaharuan yang tercermin dalam sikap dan gaya kepemimpinan pemimpin dalam berinteraksi dengan guru dan karyawan.

Peneliti ingin mengulas lebih dalam tentang masalah -masalah yang mengganggu keefektifan kinerja guru yang kerap kali muncul dengan melihat gaya kepemimpinan yang diterapkan di Madrasah Ibtidaiyah Mujahidin Loloan Barat, dalam hal ini dapat dilihat dari guru

12 Mulyasa, Manajemen Berbasis Sekolah (Konsep, Strategi, dan Implementasi), (Bandung: Remaja Rosdakarya, 2005), h. 85

${ }^{13}$ Ibid., h. 82 
(pendidik) sering absen tanpa meninggalkan tugas sehingga murid tidak terkendali dan kegiatan belajar mengajar terganggu. Pada penilaian kinerja guru maka peneliti mengacu pada Permendiknas No.16 Tahun 2007 tentang standar kualifikasi akademik dan kompetensi guru.

Berdasarkan deskripsi di atas, maka peneliti ingin mengambil penelitian Manjemen Kepemimpinan Kepala Sekolah Dalam Peningkatan Kinerja Guru di Madrasah Ibtidaiyah Mujahidin Loloan BaratDenpasar Metode Penelitian

Penelitian yang mengangkat topik tentang "manajemen layanan bimbingan dan konseling: sebuah pendekatan untuk mereduksi perilaku prokrastinasi akademik ini menggunakan paradigma post-positivisme atau paradigm kualitatif. Guba dan Lincoln menyatakan, dalam paradigma ini raelitas itu diasumsikan ada akan tetapi pengertiannya tidak dapat dipahami secara sempurna karena kelemahan intelektual dan fenomena alam yang mudah berubah. ${ }^{14}$ Realitas itu ganda, sehingga realitas itu tidak dapat dipisah-pisah sama lain, akan tetapi harus dilakukan secara holistik, tanpa rekayasa. Oleh karena itu, perlu keterlibatan subjektif untuk memudahkan memahami realitas sedekat mungkin dengan kenyataan yang sesungguhnya. ${ }^{15}$ Penelitian ini mengambil bentuk penelitian yang bersifat deskriptif kualitatif, yaitu proses penelitian yang menghasilkan data deskriptif sebagaimana adanya (natural setting) yang berupa katakata tertulis dari orang-orang atau perilaku yang diamati. Juga merupakan suatu konsep untuk mengungkapkan rahasia tertentu, yang dilakukan dengan cara menghimpun data dalam keadaan yang alamiah, sistematis dan terarah mengenai suatu masalah dalam aspek atau bidang kehidupan tertentu. ${ }^{16}$ Dalam hal ini ada beberapa data yang peneliti ambil ketika dilapangan berupa foto, videotape atau segala jenis suara/bunyi.${ }^{17}$ analisis

${ }^{14}$ Egon G. Guba dan Yvonna S. Lincoln, "berbagai Paradigma yang Bersaing dalam Penelitian Kualitatif", dalam Norman K. Denzin dan Yvonna S. Lincoln, Handbook of Qualitative Research, Terj, Zuhri Qudsy, (Yogyakarta: Pustaka Pelajar, 2009), 136.

${ }^{15}$ Moh Kasiram, Metodologi Penelitian Kuantitatif-Kualitatif, Cet. II, (Malang: UIN Maliki Press, 2010), 150.

${ }^{16}$ Lexy J Moleong, Metode Penelitian Kualitatif, (Bandung: PT Remaja Rosdakarya, 1993), 3.

17 John W. Creswell, Research Design Qualitative, Quantitative, and Mixed Methods Approaches, Third Edition, Achmad Fawaid (terj), (Yogyakarta: Pustaka Pelajar, 2013), 270. 
data yang duganakan terdiri dari tiga alur kegiatan secara bersamaan yaitu reduksi data, penyajian data dan penarikan kesimpulan. ${ }^{18}$

\section{PEMBAHASAN}

Hasil observasi yang dilakukan oleh penulis pada tanggal 14 Februari 2021 pukul 10:46, penulis bertemu dengan Dwi Nur Hidayati selaku kepala RA. Dalam pertemuan tersebut penulis menanyakan tentang gaya kepemimpinan kepala sekolah. Diketahui bahwa di Madrasah Ibtidaiyah Mujahidin Loloan Barat menggunakan 2 gaya kepemimpinan yaitu gaya demokrasi dan gaya otoriter atau otokrasi. Dalam hal ini sesuai wawancara yang dilakukan oleh penulis. Adapun petikan wawancara sebagai berikut :

.... Dalam meningkatkan kinerja guru, saya (kepala sekolah) menggunakan 2 gaya kepemimpinan, yaitu gaya demokrasi dan gaya otoriter. Tidak semua yang dilakukan menggunakan gaya kepemimpinan demokrasi, gaya kepemimpinan otoriter saya (kepala sekolah) gunakan apabila terdapat permasalahan yang mendesak, akan tetapi tetap gaya kepemimpinan demokrasi yang paling dominan. ${ }^{19}$

Dari hasil wawancara dapat disimpulkan bahwa kepala sekolah di Madrasah Ibtidaiyah Mujahidin Loloan Barat menggunakan dua gaya kepemimpinan yaitu gaya kepemimpinan demokrasi dan gaya kepemimpinan otoriter (otokrasi). Dalam hal ini gaya yang diterapkan lebih dominan pada gaya kepemimpinan demokrasi karena gaya demokrasi kepala sekolah lebih flexibel dalam menghadapi permasalahan guru dan kepala sekolah lebih mementingkan kepentingan bersama daripada kepentingan sendiri, sehingga terciptalahhubungan dan kerjasama yang baik, harmonis, saling membantu di dalam melaksanakan tugas sehari -hari dan akan tercipta suasana yang sehat.

Akan tetapi apabila ada suatu permasalahan yang mendesak, maka gaya kepemimpinan kepala sekolah Madrasah Ibtidaiyah Mujahidin Loloan Barat adalah gaya kepemimpinan otoriter (otokrasi) karena guru tidak memahami tugas yang harus dilaksanakan sebagai seorang pendidik dan masih memerlukan petunjuk dari kepala sekolah serta belum bisa menentukan apa yang harus (baik) untuk dikerjakan.

18 Miles and Huberman, Analisis Data Kualitatif, (Jakarta: Universitas Indonesia Press, 1992), 16

19 Dwi Nur Hidayati, kepala Madrasah Ibtidaiyah Mujahidin Loloan Barat, Wawancara, Denpasar tanggal 14 Februari 2021 
Sedangkan untuk mengetahui faktor pendukung gaya kepemimpinan tersebut maka diperlukan suatu penilaian. Dalam hal ini hasil wawancara antara kepala sekolah dengan penulis, yaitu:

... Pada awal saya (kepala) menjabat menjadi kepala sekolah di sini (Madrasah Ibtidaiyah Mujahidin Loloan Barat) banyak guru yang sering meninggalkan kelas tanpa izin dan sering tidak masuk tanpa izin, tetapi setelah saya (kepala sekolah) telusuri saya memutuskan untuk melakukan penilaian dengan supervisi kelas dan supervisi klinis dengan teknik observasi kelas karena menurut saya (kepala RA) itu sudah memenuhi dalam pembinaan, keteladanan dan dapat mengevaluasi kinerja guru dan tidak lupa dari semua itu tetap disertai hubungan yang murni (kekeluargaan) dan silaturrahmi yang diadakan 2 bukan sekali agar terjadi tegur sapa antara guru dengan guru lainnya... ${ }^{20}$

Dengan wawancara dan dialog antara kepala RA dengan penulis dapat diperoleh informasi bahwa untuk menunjang keaktifan guru di dalam kelas serta menilai kinerja guru, kepala sekolah menggunakan supervisi kelas dan supervisi klinis dengan teknik observasi kelas karena dari semua itu dapat meningkatkan kinerja guru secara maximal dan dapat merealisasikan suatu kegiatan yang telah direncanakan. Selain itu dengan supervisi tersebut nantinya akan memunculkan sikap keteladanan yang dilakukan oleh kepala sekolah, yaitu :

a. Sikap penuh persahabatan selalu ditujukan pada saat melakukan supervisi

b. Memperlakukan guru sebagai sejawat bukan perlakuan atasan dengan bawahan, sehingga akan timbul suasana yang penuh kebersamaan

c. Memahami kesulitan guru dan memberikan masu kan jika guru memperlakukan beberapa kesalahan kecil dalam menerapkan strategi pembelajaran

d. Memberikan dorongan agar guru melaksanakan tugasnya dengan baik dan mendiskusikan masalah yang ditemui oleh guru dalam menjalankan tugasnya. ${ }^{21}$

Meskipun kepala sekolah menerapkan gaya kepemimpinan demokrasi, sikap disiplin harus tetap diterapkan, karena akan mempengaruhi kinerja guru. Apabila kepala sekolah mendapati guru yang

\footnotetext{
${ }^{20}$ Ibid

${ }^{21}$ Ibid
} 
tidak melaksanakan tugas sebagaimana mestinya, kepala sekolah akan menegur dengan cara baik-baik yaitu dengan mengajak sharing dan terus memberi motivasi. Apabila dengan cara demokrasi guru tetap tidak melakukan perubahan terhadap dirinya, maka dengan terpaksa kepala sekolah memimpin dengan gaya otoriter pada guru tersebut dengan memberi skors dan sebagian tugasnya digantikan pada guru lain serta jadwal mengajar juga sebagian dikurangi. Apabila masih saja melakukan kesalahan, kepala sekolah harus mengambil sifat tegas dengan cara diberhentikan dari pekerjaannya.

Guna mendukung data tentang gaya kepemimpinan tersebut, penulis menelusuri dengan menanyakan gaya kepemimpinan kepala sekolah terhadap guru kelas, berikut petikan wawancara penulis dengan Sherly Rahmawati Putri, guru kelompok A, R.A Anak Mulia,

Kepala sekolah (Dwi Nur Hidayati) sepengetahuan saya dalam memimpin sekolah demokratislah ya terkadang juga otiriter, itupun jika menghadapi situasi tertentu, misalnya guru yang tidak disipilin. Gaya kepemimpinannya luwes dan menyenangkan..... ${ }^{22}$

Untuk mendukung pendapat ibu Sherly tersebut, penulis melanjutkan pertanyaan yang sama kepada ibu Mujiana Wati, Tata Usaha RA Anak Mulia:

Kepemimpinan Ibu Dwi di sini sangat demokratis,selalu terbuka terhadap pendapat dan usulan guru maupun karyawan, terkadang agak otoriter dalam situasi tertentu ${ }^{23}$

Untuk menguatkan data tersebut, penulis mencari inforamasi dari luar lingkungan sekolah, yaitu dengan menggali informasi dari salah satu wali murid, Ibu Siti Juwairiyah, berikut ini petikan wawancaranya:

Sepengetahuan saya Ibu Kepala RA disni orang luwes, enak cara memimpinnya, kalau gayanya saya kurang tahu apa namanya, Cuma Ibu Dwi (kepala RA) itu saya lihat komunikasinya enak sama guru-guru, sama wali murid juga tidak segan bertegur sapa, intinya tidak galaklah..."24

${ }^{22}$ Sherly Rahmawati Putri, Guru Kelompok A, Madrasah Ibtidaiyah Mujahidin Loloan Barat. Wawancara, Denpasar Tanggal 21 Januari 2021.

${ }^{23}$ Mujiana Wati, Kabag Tata Usaha RA Anak Mulia Denasar, Wawancara, denpasar Tanggal 8 Januari 2021

${ }^{24}$ Siti Juwairiyah, Wali Murid Madrasah Ibtidaiyah Mujahidin Loloan Barat, Wawancara, Denpasar, 8 Januari 2021 
Begitu juga dengan komite sekolah yang penulis temui mengemukakan pendapatnya sebagai berikut:

Kepala RA Anak Mulia yang sekarang bagus, gaya kepemiminannya saya suka, tidak semaunya sendiri, terbuka terhadap saran dan pendapat orang di sekitarnya, demokratis, luwes dan ramah. Ya sesekali agak otoriter jika berhadapan dengan kedisiplinan dan evaluasi kinerja. Saya sebagai komite terus mendukung kepmimpinannya. ${ }^{25}$

Dari hasil wawancara tersebut memberikan penjelasan bahwa gaya kepemimpinan kepala sekolah di RA Anak Mulia menggunakan gaya Demokratis namun tetap dengan kedisipilinan, selain itu dalam kondisi tertentu kepala RA Anak Mulia menggunakan gaya otoriter, misalnya dalam menghadapi ketidak disiplinan guru setelah diberi arahan dan teguran.

\section{Kinerja Guru di Madrasah Ibtidaiyah Mujahidin Loloan Barat}

Sebagaimana diketahui bahwa dalam peraturan Menteri Pendidikan Nasional No. 16 Tahun 2007 tentang kualifikasi dan kompetensi guru meliputi kompetensi pedagogik, kompetensi kepribadian, kompetensi sosial dan kompetensi profesional.

\section{Kompetensi Pedagogik}

Pada Madrasah Ibtidaiyah Mujahidin Loloan Barat, setiap guru harus memiliki kompetensi pedagogik karena dengan memiliki kompetensi tersebut maka guru akan cepat memahami peserta didiknya. Untuk mengetahui karakteristik guru ini, guru -guru di Madrasah Ibtidaiyah Mujahidin Loloan Barat dengan hasil observasi yang diwakili oleh masing-masing Guru kelompok. Adapun kompetensi guru di Madrasah Ibtidaiyah Mujahidin Loloan Barat meliputi :

1) Menguasai karakteristik peserta didik dari aspek fisik, moral, spiritual, sosial, kultural emosional dan intelektual yaitu dengan cara berinteraksi di kelas dengan peserta didik, meningkatkan komunikasi dengan peserta didik dan memberikan contoh atau menjadi teladan bagi peserta didik.

2) Menguasai teori belajar dan prinsip pembelajaran yang mendidik yaitu dengan cara memahami dan mengulas kembali apa yang mau diberikan oleh peserta didik, memotivasi siswa belajar sejak saat membuka sampai menutup pelajaran, dan dengan menggunakan bahasa yang

${ }^{25}$ Nurul Juwita, Ketua Komite Madrasah Ibtidaiyah Mujahidin Loloan Barat, Wawancara, Denpasar 9 Januari 2021 
komunikatif maka peserta didik tidak akan merasa takut dan akan termotivasi pada pembelajaran tersebut.

3) Menyelenggarakan pembelajaran yang mendidik dengan cara membuat rencana pelaksanaan pembelajaran yang meliputi:

a) Standar kompetensi

b) Kompetensi dasar

c) Indikator yang terangkum dalam tujuan pembelajaran dan materi pokok

d) Metode/teknik pembelajaran

e) Kegiatan pembelajaran

f) Alokasi waktu

g) Sumber atau bahan atau alat

h) Penilaian

4) Menyelenggarakan penilaian dan evaluasi, proses dan hasil belajar, serta mengevaluasi dengan cara mempersilahkan atau menyuruh siswa maju ke depan untuk mengukur konsentrasi peserta didik. ${ }^{26}$

Kompetensi Pribadi

Kepribadian yang mantap dari sosok seorang guru akan memberikan teladan yang baik terhadap peserta didik. Adapun kompetensi kepribadian yang dimiliki pada guru Madrasah Ibtidaiyah Mujahidin Loloan Barat, meliputi :

1) Bertindak sesuai norma agama, hukum, sosial, dan kebudayaan nasional Indonesia yaitu dengan cara menumbuhkan mentalitas jujur, ikhlas, bersedia bekerja keras dan bermoral.

2) Menunjukkan etos kerja, tanggung jawab yang tinggi, rasa bangga menjadi guru, dan rasa percaya diri yaitu dengan cara menjadikan anak didik kreatif dan berprestasi.

3) Menjunjung tinggi kode etik profesi guru yaitu dengan cara komunikasi guru dan anak didik di dalam dan di luar sekolah dilandaskan pada rasa kasih sayang, guru harus mengetahui kepribadian anak dan latar belakang masing-masing siswa dan guru menciptakan suasana kehidupan sekolah sehingga anak didik betah berada dan belajar di sekolah. ${ }^{27}$

Kompetensi Sosial

${ }^{26}$ Laily Yasmin, Guru Kelompok B, Madrasah Ibtidaiyah Mujahidin Loloan Barat, wawancara dan dokumentasi arsip tanggal 14 Januari 2021

${ }^{27}$ Data dokumentasi Madrasah Ibtidaiyah Mujahidin Loloan Barat 
Agar setiap guru mampu beradaptasi dengan lingkungan, maka guru di Madrasah Ibtidaiyah Mujahidin Loloan Barat harus menguasai dan memiliki kompetensi sosial yang meliputi :

1) Bersikap inklusif, bertindak objektif, serta tidak diskriminatif yaitu dengan cara tidak membeda-bedakan peserta didik dalam semua hal meliputi jenis kelamin, agama, ras, kondisi fisik, latar belakang keluarga, dan status sosial ekonomi.

2) Berkomunikasi secara efektif, empatik dan santun dengan sesama pendidik, tenaga kependidikan, orang tua dan masyarakat dengan cara saling bertegur sapa dengan program di sekolah (Madrasah Ibtidaiyah Mujahidin Loloan Barat) yaitu silaturrahmi yang diadakan 2 bulan sekali. Hal ini sesuai dengan wawancara yang dilakukan oleh penulis sebelumnya kepada Dwi Nur Hidayati selaku Kepala Sekolah yaitu :

... Dalam meningkatkan keharmonisan dalam lembaga di Madrasah Ibtidaiyah Mujahidin Loloan Barat mempunyai program mengadakan hubungan yang murni (kekelurgaan) dan silaturrahmi yang diadakan 2 bulan sekali agar terjadi tegur sapa antara guru satu dengan guru yang lainnya.... ${ }^{28}$

Begitu juga penulis melakukan wawancara dengan salah satu guru kelompok A. penulis menanyakan hal yang sama tentang kompetensi sosial yang dimiliki pada guru di Madrasah Ibtidaiyah Mujahidin Loloan Barat, yaitu :

... Guru di sini tidak pernah terlepas dari keakraban karena di setiap ada permasalahan yang berhubungan dengan pembelajaran, guru di Madrasah Ibtidaiyah Mujahidin Loloan Barat ini dibiasakan untuk sharing...$^{29}$

Dari kedua sumber tersebut dapat disimpulkan bahwa pada Madrasah Ibtidaiyah Mujahidin Loloan Barat hubungan sosial seluruh tenaga pendidikan sangat harmonis dan terjalin erat serta ramah dalam bertegur sapa.

Kompetensi Profesional

Keprofesionalan guru di Madrasah Ibtidaiyah Mujahidin Loloan Barat dituntut dalam penguasaan materi pelajaran secara luas dan mendalam. Maksudnya adalah kemampuan dalam menguasai ilmu,

\footnotetext{
${ }^{28}$ Dwi Nur Hidayati, Op. Cit

29 Siti Mukarromah, Guru Kelompok A RA Anaka Mulia Denpasar,
} Wawancara, Denpasar, tanggal 7 Januari 2021 
jenjang dan jenis pendidikan yang sesuai. Adapun kompetensi profesional meliputi :

1) Menguasai materi, struktur, konsep, dan pola pikir keilmuan yang mendukung mata pelajaran yang diampu dengan cara mengikuti bahan ajar secara benar, mengerti konteks ilmu yang hendak diajarkan dan jenjang pendidikan yang telah ditempuh.

2) Menguasai standar kompetensi dan kompetensi dasar mata pelajaran atau bidang pengembangan yang diampu dengan cara mengikuti silabus dan pemetaan kompetensi dasar aspek penilaian.

3) Mengembangkan materi pembelajaran yang diampu secara kreatif dengan menentukan media dan metode pembelajaran dari tiap-tiap pertemuan. Hal ini dilakukan agar peserta didik selalu bersemangat dan termotivasi untuk lebih meningkatkan prestasi dan kreativitas.

Manajemen Kepemimpinan Kepala Sekolah Dalam Peningkatan Kinerja Guru di Madrasah Ibtidaiyah Mujahidin Loloan Barat.

Dapat diketahui dari pembahasan sebelumnya bahwa kepala sekolah Madrasah Ibtidaiyah Mujahidin Loloan Barat menerapkan gaya kepemimpinan demokratis yaitu mementingkan kepentingan bersama daripada kepentingan pribadi, memberikan kebebasan pada bawahan dalam memajukan lembaga tetapi tetap pada pengawasan kepala sekolah, dan mengembangkan kapasitas sebagai pemimpin.

Hal ini sesuai hasil wawancara dengan Dwi Nur Hidayati selaku kepala Madrasah Ibtidaiyah Mujahidin Loloan Barat, yaitu :

...Saya (kepala sekolah) menggunakan gaya kepemimpinan demokratis agar bawahan (guru dan karyawan) merasa nyaman dan dihargai karena saya (kepala sekolah) lebih mementingkan tujuan bersama daripada kepentingan pribadi dengan cara kekeluargaan dan saya menggunakan gaya kepemimpinan otoriter apabila ada permasalahan yang mendesak sehingga saya tidak mau menerima pendapat, saran dan kritik dan sudah pasti saya menggunakan jabatan saya secara formalitas sebagai kepala sekolah dalam pengambilan keputusan.... ${ }^{30}$

Kemudian penulis melanjutkan dengan pertanyaan dalam peningkatan kinerja guru di Madrasah Ibtidaiyah Mujahidin Loloan Barat, yaitu :

...Dalam peningkatan kinerja guru di Madrasah Ibtidaiyah Mujahidin Loloan Barat ini saya (kepala sekolah) melakukan penilaian dengan melihat kompetensi guru tersebut yaitu kompetensi pedagogik, kepribadian, sosial, dan profesionalnya

${ }^{30}$ Dwi Nur Hidayati Op.Cit 
yaitu dengan cara melakukan kegiatan harian, mingguan, bulanan dan semester... ${ }^{31}$

Dari hasil wawancara di atas, dapat disimpulkan bahwa pada Madrasah Ibtidaiyah Mujahidin Loloan Barat menggunakan gaya kepemimpinan demokratis yaitu selalu berusaha untuk mengutamakan gaya kepemimpinan organisasi dari pada kepentingan dan tujuan pribadi, mengutamakan kerjasama dalam mencapai tujuan serta mengusahakan agar bawahan dapat lebih sukses daripada dirinya, dan gaya kepemimpinan otoriter hanya digunakan apabila terdapat permasalahan yang mendesak, sedangkan dalam penilaian kinerja guru dapat dilihat dari kompetensi guru yaitu kompetensi pedagogik, kepribadian, sosial, dan profesionalnya yang meliputi :

a. Kegiatan harian

1) Daftar hadir guru, tenaga teknis kependidikan dan tenaga tata usaha serta jadwal kelas

2) Mengatur dan memeriksa kegiatan (keagamaan, keamanan, kebersihan, keindahan, ketertiban, kekeluargaan, dan kesehatan)

3) Mengatasi hambatan-hambatan yang timbul dalam kegiatan belajar mengajar

4) Mengatasi kasus yang terjadi pada waktu itu

5) Memeriksa segala sesuatu menjelang selesainya kegiatan belajar mengajar

b. Kegiatan mingguan

1) Upacara bendera setiap hari Senin dan hari -hari istimewa

2) Mengadakan rapat atau evaluasi guru membahas jalannya pembelajaran yang telah berlangsung dan beberapa kasus yang belum terselesaikan dengan staf pimpinan.

c. Kegiatan bulanan

1) Kumpulan bahan evaluasi berikut bahan analisisnya, kumpulan satuan pelajaran, kumpulan kriteria ketuntasan minimal, buku catatan harian dan analisis hasil butir soal ulangan dan program tindak lanjut seperti : nilai maksimal, skor yang diperoleh, dan nilai ketuntasan.

2) Memberikan petunjuk atau catatan kepada guru tentang siswasiswa yang perlu dibantu dalam rangka pembinaan kegiatan siswa

d. Kegiatan semester

1) Menyiapkan dan memeriksa buku induk

${ }^{31}$ Ibid 
2) Mengadakan supervisi kelas (observasi kelas) saat proses KBM berjalan mengenai kelengkapan administrasi guru mengajar.

3) Menyelenggarakan kegiatan semester tentang siswa yang perlu mendapat perhatian khusus, pengisian nilai semester, pembagian raport, dan memanggil orang tua siswa. ${ }^{32}$

Jadi dapat disimpulkan bahwa gaya kepemimpinan kepala sekolah dalam peningkatan kinerja guru di Madrasah Ibtidaiyah Mujahidin Loloan Barat menggunakan dua gaya kepemimpinan yaitu gaya demokrasi dan gaya otoriter, akan tetapi lebih dominan menggunakan gaya kepemimpinan demokratis dengan melihat kompetensi guru melalui kegiatan -kegiatan harian, mingguan, bulanan dan semester.

Ungkapan senada juga diutarakan oleh Laily Yasmin, Guru kelompok B2 sebagai berikut:

Kinerja guru disini selalu dievaluasi oleh kepala (ibu Dwi Nur Hidayati), ada kegiatan harian, mingguan, bulanan dan tiap semester, penilian itu biasanya meliputi kompetensi pedagogik, kepribadian, social. Kedisipilinan guru disini selalu dipantau namun dengan cara yang enak, sederhana dan disukai guruguru.."33

Kemudian penulis melanjutkan pertanyaan yang sama terhadap Sherly Rahmawati Putri, sebagai berikut:

Ya memang ada evaluasi kinerja dari kepala di sini, dengan melakukan kegiatan harian, mingguan, bulanan dan semester, dengan bentuk tidak memberatkan guru-guru, ya demokratislah caranya... ${ }^{34}$

Dari hasil yang didapatkan oleh penulis, bahwa selain tugas-tugas kepala sekolah yang dilakukan dalam supervisi terhadap guru dan karyawan, juga mempunyai kesepakatan dalam menumbuhkan budaya malu, yaitu :

a. Malu karena datang terlambat

b. Malu karaena melihat rekan sibuk melakukan aktivitas

${ }^{32}$ Data hasil dokumentasi Madrasah Ibtidaiyah Mujahidin Loloan Barat

${ }^{33}$ Lailiy Yasmin, Guru kelompok B2 Madrasah Ibtidaiyah Mujahidin Loloan Barat. Wawancara, Denpasar 8 Januari 2021

${ }^{34}$ Sherly Rahmawati Putri, guru Kelompok B2 Madrasah Ibtidaiyah Mujahidin Loloan Barat, Wawancara, Denpasar 8 Januari 2021 
c. Malu karena melanggar peraturan

d. Malu untuk berbuat salah

e. Malu karena bekerja tidak berprestasi

f. Malu karena tugas tidak terlaksana atau selesai tepat waktu

g. Malu karena tidak berperan aktif dalam mewujudkan lingkungan bersih $^{35}$

\section{KESIMPULAN}

Manajemen kepemimpinan kepala sekolah di Madrasah Ibtidaiyah Mujahidin Loloan Barat lebih dominan menggunakan gaya kepemimpinan demokratis dan dalam pengambilan keputusan yang mendesak, gaya kepemimpinan yang digunakan adalah gaya kepemimpinan otokrasi atau otoriter. Kinerja guru di Madrasah Ibtidaiyah Mujahidin Loloan Barat dapat dikatakan sangat baik dan tingkat tinggi karena dengan melihat kompetensi guru yang meliputi kompetensi paedagodik, kompetensi kepribadian, kompetensi sosial, dan kompetensi profesional, sehingga kinerja di lembaga tersebut dapat terlaksana dengan baik dan terkendali.

Manajemen kepemimpinan kepala sekolah dalam peningkatan kinerja guru di Madrasah Ibtidaiyah Mujahidin Loloan Barat dapat dikatakan sangat baik dengan menggunakan gaya kepemimpinan demokratis dan otoriter serta supervisi observasi kelas dalam kegiatankegiatan, yaitu kegiatan harian, mingguan, bulanan, dan semester. Dari semua itu dapat meningkatkan kinerja guru yang terlihat dalam kompetensi paedagogik, kompetensi kepribadian, kompetensi sosial, dan kompetensi profesional dengan tingkat tinggi serta didukung oleh tumbuhnya budaya malu.

\section{DAFTAR PUSTAKA}

Bennis, Warren \& Nanus, Bart, 1990, Kepemimpinan Strategi dalam Mengemban Tanggung Jawab. Jakarta: Gelora Aksara Pratama.

Creswell, John W, 2013, Research Design Qualitative, Quantitative, and Mixed Methods Approaches, Third Edition, Achmad Fawaid (terj), Yogyakarta: Pustaka Pelajar.

${ }^{35}$ Data dokumentasi Madrasah Ibtidaiyah Mujahidin Loloan Barat 
Departemen Agama RI, 2006, Al Quran dan terjemahannya, Bandung: Syamil Cipta Media.

Guba, Egon G, dan Lincoln, Yvonna S, 2009, "berbagai Paradigma yang Bersaing dalam Penelitian Kualitatif", dalam Norman K. Denzin dan Yvonna S. Lincoln, Handbook of Qualitative Research, Terj, Zuhri Qudsy, (Yogyakarta: Pustaka Pelajar.

http://meetabied.wordpress.com/2009/12/24/gaya-kepemimpinan/ diakses pada tanggal 21 Maret 2021.

Huberman, Miles, 1992, Analisis Data Kualitatif, Jakarta: Universitas Indonesia Press.

Ismailal-Bukhori, Abi Abdillah Muhammad Ibn, Al Jami' Al-Shahih, (Al Qahirah: Al Matba'ah al Salafiyah,1403 H.

Kasiram, 2010, Metodologi Penelitian Kuantitatif-Kualitatif, Cet. II, (Malang: UIN Maliki Press.

Kast, Fremont dan Resenzweig, 1991, Organisasi dan Manajemen 2, Jakarta: Bumi Aksara.

Kenneth N. Wexlwy, Gary A. Yuki, 1992, Perilaku Organisasi dan Psikologi Personalia, Jakarta: Rineka Cipta.

Miftah Thoha, 1995, Kepemimpinan dalam Manajemen, Jakarta: Raja Grafindo Persada.

Moleong, Lexy J, 2002, Metodelogi Penelitian Kualitatif, Bandung: PT. Remaja Rosdakarya

Mulyasa, 2005, Manajemen Berbasis Sekolah Konsep, Strategi, dan Implementasi), Bandung: Remaja Rosdakarya.

Purwanto, Ngalim, 2006, Administrasi dan Supervisi Pendidikan, Bandung: Remaja Rosdakarya.

Rifa'I, 1986, Administrasi dan Supervisi Pendidikan, Bandung: Jemmar.

Suprayogo, Imam 1999, Revormulasi Visi Pendidikan Islam, Malang: Stain Press.

Wahab, Abdul Aziz, 2008, Anatomi Organisasi dan Kepemimpinan Pendidikan, CV. Alfabeta. 